\title{
Managerial Innovations in Structure Capital and Important Decisions in Determining the Profit Management of Plantation Company: Empirical Evidence in ASEAN Countries
}

\author{
Sriyono Sriyono ${ }^{1}$, Detak Prapanca ${ }^{2}$, Afif Nursidah $^{3}$ \\ 1,2,3, Faculty of Business, Law, and Social Sciences \\ Universitas Muhammadiyah Sidoarjo, Indonesia
}

Email: sriyono@umsida.ac.id

\begin{abstract}
Research on the financial management of plantation company is very important, because it provides different information, especially in ASEAN countries. Several research has been conducted, but none has fully discussed how to manage its profit. Therefore, the purpose of this study is to ascertain how managerial innovation helps in deciding financial management using a profit management perspective. It is also important to strengthen financial ratios such as Current, Total Asset Turn Over, Debt to Equity, Return On Assets, and Price Earning Ratio towards Profit Changes for plantation companies listed on Indonesia (IDX) and Malaysia (BEM) Stock Exchange. Furthermore, this study also examines the cash flow patterns in the management of plantation companies listed on the IDX \& BEM. The results shows the relationship between CR, TATO, DER, ROA, and PER on company profit management was found, both in Malaysia and Indonesia. It can be concluded that both ROA and PER have positive and negative effect on profit changes, while CR, TATO, and DER variables have no significant effect in Indonesia. However, in Malaysian companies, only the DER had a significant positive effect on profit changes.
\end{abstract}

Keywords: Current Ratio, Total Asset Turn Over, Debt to Equity Ratio, Return On Asset, Price Earning Ratio and Profit Changes.

\section{INTRODUCTION}

Plantation companies are oriented towards economic and commercial operations and legally managed for profit [1] and growth (Table 1). However, it is not easy to obtain this growth because there are many challenges in their management technically both in the sector and from its method. This is due to influence from many components such as the financial sector. 
Table 1 Revenue growth from several plantation companies

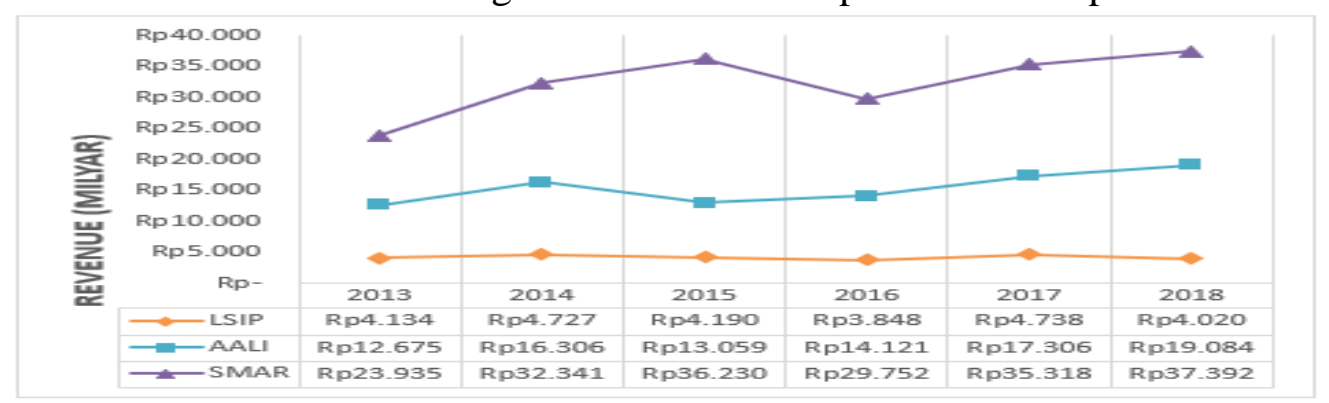

Sources: idx.co.id

According to Yusuf (2014), plantation is proven to be among the sectors able to survive in global financial crisis, even in Indonesia. Until now, this sector still contributes to the country's foreign exchange. Furthermore, plantation commodities have been developed which include oil palm, rubber, cocoa, tea and more. Therefore, the business opportunities in the sector can be trusted because of its renewable characteristics.
Malaysia is the major competitor country for Indonesian palm oil. Although they have better production and quality, the export growth is expected to be held back by limited land resources and high wage workers. Meanwhile, Indonesia can still develop because the potential land support is available, and there are opportunities to increase productivity.

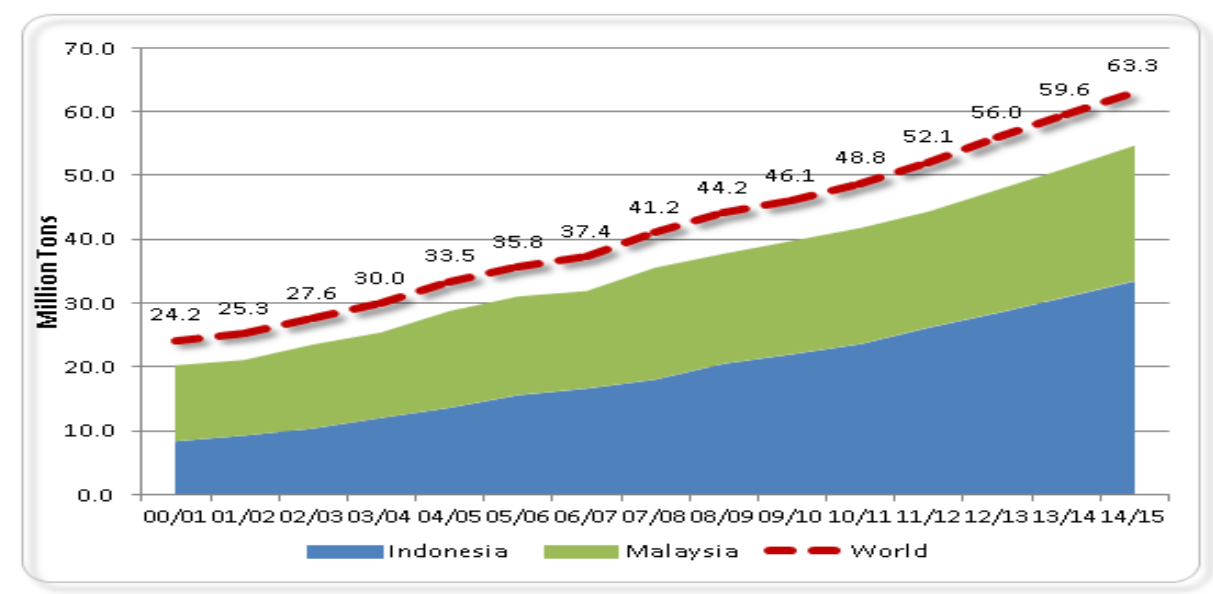

Sources: USDA-FAS, Office of Global Analysis, 2020

Figure 1. The Plantation Production Growth in Indonesia - Malaysia

Hutabarat (2013) reported that the profit change depends on revenue volatility from the two reporting periods, where it is affected by changes in the components of financial statements such as sales, cost of goods sold, operating expenses, interest expenses, income tax, extraordinary items, and others [3]. Furthermore, the 5 types of financial ratios can be a reference for investors which are leverage, liquidity, activity, profitability, and market value [4]. these findings will be a useful knowledge for real financial statements users, supposing the ratios can be used to predict future profit changes. Conversely, supposing the ratio is less significant as a predictor, then this results strengthens the inconsistency evidence of the previous empirical findings [5]. Furthermore, EPS is considered as the most basic and useful information for investors, because it describes the prospects for future company earnings [6].

Therefore, this study aims to determine the financial management characteristics of plantation companies in Indonesia and Malaysia, and how managerial innovation decides after recognizing some factors that affect earnings management. 


\section{RESEARCH METHODS}

A quantitative research method was used based on the logico-hypotheco-verificative positivism paradigm with assumptions about empirical objects. these assumptions can focus on a portion of the context in the form of certain variables from a research object, and determined to be a problem [13].

Furthermore, the population used is the entire plantation companies listed on the IDX totaling 17 and on BEM totaling 16 companies. This research used purposive sampling, and ultimately selected 10 companies in Indonesia and 11 in Malaysia.

Table 2

Plantation Companies Criteria on the IDX included in the sample

\begin{tabular}{|c|l|c|c|}
\hline No. & \multicolumn{1}{|c|}{ Sample Distribution } & \multicolumn{1}{|c|}{17} & 16 \\
\cline { 3 - 4 } 1. & $\begin{array}{l}\text { The company listed on the IDX and has published } \\
\text { financial statements for the period of 2013-2017. }\end{array}$ & Malaysia \\
\hline 2. & $\begin{array}{l}\text { Companies which present incomplete annual statements } \\
\text { variable data needed during the period of 2013-2017 }\end{array}$ & 7 & 5 \\
\hline 3. & $\begin{array}{l}\text { Companies which present complete financial statements } \\
\text { variable data }\end{array}$ & 10 & 11 \\
\hline
\end{tabular}

Operational Definition, variable identification and indicator variables

Table 3. Operational Variables and Definitions

\begin{tabular}{|c|c|c|c|}
\hline Dependent Variable: & $\begin{array}{l}\text { Measuring } \\
\text { instrument }\end{array}$ & Definition & Formula \\
\hline - $\quad$ Profit Changes & Profit Changes & $\begin{array}{l}\text { Is the comparison result } \\
\text { between earnings in a certain } \\
\text { period with the previous }\end{array}$ & $\Delta E_{n}=\frac{E_{n}-E_{n-1}}{E_{n-1}}$ \\
\hline Independent Variable : & $\begin{array}{l}\text { Measuring } \\
\text { instrument }\end{array}$ & Definition & Formula \\
\hline $\begin{array}{c}\text { - Liquidity } \\
\text { Ratio }\end{array}$ & $\mathrm{CR}$ & $\begin{array}{l}\text { [4] It is used to assess a } \\
\text { company's ability to pay its } \\
\text { current debt using current } \\
\text { assets. }\end{array}$ & $\mathrm{CR}=\frac{\text { Current Asset }}{\text { Current Liabilities }}$ \\
\hline $\begin{array}{c}\text { - Activities } \\
\text { Ratio }\end{array}$ & TATO & $\begin{array}{l}\text { [14] Total asset turn over is a } \\
\text { ratio used to assess the ability } \\
\text { of funds embedded from all } \\
\text { assets that revolve in a period } \\
\text { or the ability of capital } \\
\text { invested to generate } \\
\text { "revenue". }\end{array}$ & TATO $=\frac{\text { Penjualan Bersih }}{\text { Total Aktiva }}$ \\
\hline $\begin{array}{c}\text { - Solvency } \\
\text { Ratio }\end{array}$ & DER & $\begin{array}{l}\text { It is used to assess how much } \\
\text { the company is financed by } \\
\text { debt }\end{array}$ & $\mathrm{DER}=\frac{\text { Total Debt }}{\text { Equitas }}$ \\
\hline $\begin{array}{c}-\quad \text { - Profitability } \\
\text { Ratio }\end{array}$ & ROA & $\begin{array}{l}{[15] \text { Return on assets is used }} \\
\text { to assess management's ability } \\
\text { to obtain profitability and } \\
\text { managerial efficiency as a } \\
\text { whole }\end{array}$ & $\mathrm{ROA}=\frac{\text { Laba Bersih }}{\text { Total Aktiva }}$ \\
\hline $\begin{array}{c}\text { - Market value } \\
\text { Ratio }\end{array}$ & PER & $\begin{array}{l}\text { [4] It is used to assess how } \\
\text { investors examine the } \\
\text { company's growth prospects } \\
\text { in the future }\end{array}$ & $\mathrm{PER}=\frac{\text { Market } \text { Price per share }}{\text { Earning per share }}$ \\
\hline
\end{tabular}




\section{RESULTS AND DISCUSSION}

1) Comparative Analysis of Descriptive Statistics

INDONESIA

Table 4. Descriptive Statistics Data

\begin{tabular}{lcccccr}
\hline \hline & Y & CR & TATO & DER & ROA & \multicolumn{1}{c}{ PER } \\
\hline \hline Mean & 0.551994 & 1.897189 & 0.537581 & 1.129032 & 0.052449 & 13.94854 \\
Median & -0.135000 & 1.104064 & 0.477799 & 0.959128 & 0.052227 & 15.13196 \\
Maximum & 34.65000 & 24.89478 & 1.518848 & 2.682620 & 0.141245 & 54.73047 \\
Minimum & -7.740000 & 0.225461 & 0.000517 & 0.008036 & -0.104520 & -54.62725 \\
Std. Dev. & 5.199595 & 3.450001 & 0.340453 & 0.778027 & 0.043754 & 17.88518 \\
Skewness & 5.705714 & 6.115969 & 1.259409 & 0.284599 & -0.698104 & -1.919699 \\
Kurtosis & 38.68217 & 41.14536 & 4.599721 & 1.938078 & 4.868745 & 8.946500 \\
& & & & & & \\
Jarque-Bera & 2923.829 & 3343.102 & 18.54907 & 3.024302 & 11.33668 & 104.3788 \\
Probability & 0.000000 & 0.000000 & 0.000094 & 0.220435 & 0.003454 & 0.000000 \\
& & & & & & \\
Sum & 27.59968 & 94.85943 & 26.87905 & 56.45160 & 2.622462 & 697.4269 \\
Sum Sq. Dev. & 1324.754 & 583.2228 & 5.679509 & 29.66101 & 0.093806 & 15674.10 \\
Observations & 50 & 50 & 50 & 50 & 50 & 5
\end{tabular}

MALAYSIA

Table 5. Descriptive Statistics Data

\begin{tabular}{lcccccc}
\hline \hline & Y & CR & TATO & DER & ROA & PER \\
\hline \hline Mean & 14.24005 & 3.574468 & 0.496008 & 0.639342 & 0.059957 & 1121.695 \\
Median & -0.010000 & 2.112217 & 0.406389 & 0.610547 & 0.049843 & 688.8349 \\
Maximum & 775.0000 & 13.16169 & 1.211316 & 1.559618 & 0.232248 & 19178.54 \\
Minimum & -1.700000 & 0.318683 & 0.186451 & 0.058984 & -0.033131 & -801.3903 \\
Std. Dev. & 104.4847 & 3.279991 & 0.297835 & 0.397881 & 0.045328 & 2560.808 \\
Skewness & 7.211478 & 1.384358 & 0.820617 & 0.337881 & 1.826831 & 6.569259 \\
Kurtosis & 53.00994 & 3.952078 & 2.411247 & 2.344541 & 7.841000 & 46.67557 \\
& & & & & & \\
Jarque-Bera & 6208.160 & 19.64472 & 6.967309 & 2.031057 & 84.29786 & 4767.070 \\
Probability & 0.000000 & 0.000054 & 0.030695 & 0.362211 & 0.000000 & 0.000000 \\
& & & & & & \\
Sum & 783.2025 & 196.5958 & 27.28046 & 35.16382 & 3.297648 & 61693.23 \\
Sum Sq. Dev. & 589521.2 & 580.9504 & 4.790107 & 8.548688 & 0.110948 & $3.54 \mathrm{E}+08$ \\
Observations & 55 & 55 & 55 & 55 & 55 & 5
\end{tabular}


Table 6. Plantation Sector INDONESIA
Table 7. Plantation Sector MALAYSIA

\begin{tabular}{crrrr} 
Variable & Coefficient & Std. Error & t-Statistic & Prob. \\
\hline \hline & & & & \\
CR & -0.008961 & 0.332838 & -0.026922 & 0.9789 \\
TATO & -0.226154 & 1.039256 & -0.217611 & 0.8305 \\
DER & -0.036590 & 0.479276 & -0.076344 & 0.9401 \\
ROA & 18.58047 & 7.298334 & 2.545851 & 0.0216 \\
PER & -0.217620 & 0.060377 & -3.604335 & 0.0024 \\
C & 1.330112 & 1.312296 & 1.013576 & 0.3259
\end{tabular}

\section{DISCUSSION}

The results showed that ROA and PER were the influential and significant ratio in the Indonesian plantation sector. This indicated that entrepreneurs were more inclined to prioritizing and maximizing their assets, meaning all its fixed assets are used with optimum process conditions and maximum capacity [16]. Therefore, the company's fixed cost will be reduced by maximizing its assets. The company will also have more opportunities to invest than to increase its assets for production.

Through investment in fixed assets, the CPO competitiveness will be supported in the international market through import-export, because it has large plantations. Furthermore, Indonesian plantation companies are oriented to plant assets effectiveness in their contribution towards the profits received by the company.

The high CPO exports in Indonesia cannot be separated from its production influence, which tends to increase, and higher than in Malaysia. This is because Indonesia has extensive land for oil palm plantation, and it increases every year. This is one proof that investment in land expansion is prioritized to support the economic growth in the sector.

Meanwhile, the research showed that only the DER ratio has a significant effect on the Malaysian plantation sector. This can be interpreted that Malaysian companies have used capital structure strategies and debt policies for productive businesses. In addition, productive debt produces a company's assets which can either increase in value or generate passive income in the future. Large Indonesian companies need more financial support
Variable Coefficient Std. Error t-Statistic Prob.

\begin{tabular}{crrrr}
\hline \hline & & & & \\
CR & 11.19269 & 9.532497 & 1.174162 & 0.2475 \\
TATO & -130.1486 & 131.6680 & -0.988460 & 0.3290 \\
DER & 355.4110 & 69.16032 & 5.138944 & 0.0000 \\
ROA & 422.2746 & 355.0431 & 1.189362 & 0.2415 \\
PER & -0.003363 & 0.005693 & -0.590655 & 0.5582 \\
C & -209.9888 & 84.34351 & -2.489686 & 0.0172 \\
\hline \hline
\end{tabular}

because the internal funds are sometimes insufficient to run its operations, and tend to use external funds such as a debt policy strategy. Meanwhile, small companies generally do not have a strong position on debt issues, because they have limited loan capabilities.

Furthermore, the important limitation of this study is that Malaysian companies have adopted the International Financial Accounting Standards (IFRS). Meanwhile, the financial statements of plantation companies currently listed on the Indonesia Stock Exchange still use historical cost concept (book value) to present the plant assets value (Statement of Financial Accounting Standards / PSAK No. 16). Therefore, differences in plant assets system recording directly affects the equity position in other parts.

\section{CONCLUSION}

Companies in different countries have management innovation because of macroeconomic situations and cultural character, including the plantation companies in Indonesia and Malaysia. Also, the management system implemented by plantation sector companies in both countries is one of the striking differences in this study. In Indonesia, the importance of large revenues is prioritized, which is used for investment and ultimately generate profits for companies. Whereas in Malaysia, external companies funds are used such as debt policy strategy. The aim of this strategy is to create productive debt that can produce a company's assets which can either increase in value or generate income in the future. 


\section{REFERENCES}

[1] B.-S. Indonesia, "Statistical Yearbook Of Indonesia 2016 [Online] Https://Www. Bps. Go. Id/Website/Pdf_Publikasi," Stat. Pdf (Accessed December 30, 2016), 2016.

[2] H. Yusuf, "Analisis Pengaruh Profitabilitas Berbasis Nilai Tanaman Terhadap Rasio Penilaian Perusahaan Perkebunan Di Bursa Efek Indonesia Dan Singapore (Tinjauan Atas Perbandingan Pengukuran Nilai Historis Dan Nilai Wajar Pada Aset Tanaman)." Universitas Terbuka, 2014.

[3] S. Hutabarat, "Pengaruh Rasio Likuiditas, Solvabilitas, Aktivitas, Profitabilitas Dan Rasio Pasar Terhadap Perubahan Laba (Studi Kasus Perusahaan Sektor Telekomunikasi Terdaftar Di

Bursa Efek Indonesia)," Mix J. Ilm. Manaj., Vol. 3, No. 2, 2013.

[4] I. M. Sudana, "Manajemen Keuangan Perusahaan Teori Dan Praktik," Erlangga. Jakarta, 2011.

[5] C. Primayuta, "Rasio Keuangan Dan Prediksi Perubahan Laba Perusahaan Manufaktur Yang Terdaftar Di Bursa Efek Indonesia," 2009.

[6] E. Tandelilin, "Analisis Investasi Dan Manajemen Portofolio." Yogyakarta: Bpfe, 2001.

[7] S. W. Suprihatmi, "Pengaruh Rasio Keuangan Terhadap Kemampuan Memprediksi Perubahan Laba Pada Perusahaan-Perusahaan Manufaktur Yang Terdaftar Di Pt Bursa Efek Jakarta," Ekon. Dan Kewirausahaan, Vol. 6, No. 1, 2012.

[8] H. A. Maith, "Analisis Laporan Keuangan Dalam Mengukur Kinerja Keuangan Pada Pt. Hanjaya Mandala Sampoerna Tbk.," J. Emba J. Ris. Ekon.
Manajemen, Bisnis Dan Akunt., Vol. 1, No. 3, 2013.

[9] S. Sriyono, D. Prapanca, And A. S. Budi, “ Analisis Return On Equity (Roe), Current Ratio (Cr), Net Profit Margins (Npm), Dan Debt To Equity Ratio (Der) Terhadap Earning Per Share (Eps)," Jbmp (Jurnal Bisnis, Manaj. Dan Perbankan), Vol. 4, No. 2, Pp. 154-163, 2019.

[10] M. S. Widhi And P. Prajitno, "Analisis Kemampuan Rasio-Rasio Keuangan Dalam Memprediksi Perubahan Laba." Universitas Diponegoro, 2011.

[11] H. Simamora, "Akuntansi Basis Pengambilan Keputusan Bisnis Jilid Ii. Jakarta: Salemba Empat. Soemarsono. 2004," Akunt. Suatu Pengantar, Buku I, 2000.

[12] T. Nurmalasari, "Analisis Pengaruh Rasio Keuangan Terhadap Perubahan Laba Pada Perusahaan Manufaktur Yang Terdaftar Di Bursa Efek Indonesia (Bei)," 2012.

[13] M. P. K. Sugiyono And R. D. Kualitatif Dan, “ Bandung: Alfabeta." Cv, 2011.

[14] N. Amalina And A. Sabeni, "Analisis Rasio Keuangan Dalam Memprediksi Perubahan Laba:(Studi Empiris Pada Perusahaan Manufaktur Yang Terdaftar Pada Bursa Efek Indonesia Periode Tahun 2008-2011)." Fakultas Ekonomika Dan Bisnis, 2013.

[15] A. L. K. Kasmir And E. Revisi, Rajawali Pers. Jakarta, 2013.

[16] Choto, A., Thongurai, C., Kladkaew, N., \& Kiatweerasakul, M. (2014). Sterilization of Oil Palm Fruit Using Radio-Frequency Heating. International Journal of Advances in Chemical Engineering and Biological Sciences (IJACEBS), 1(1), 123-126. 